\title{
CO-DIGESTION OF GREASY WASTE AND MBR SLUDGE USING BIO-AUGMENTED PSEUDOMONAS PUTIDA: EFFECT OF BUFFERING AGENTS
}

\author{
Vongsadet Phommachanh $^{1}$, Wilai Chiemchaisri*2 ${ }^{\text {, and Chart Chiemchaisri }}{ }^{3}$ \\ 1,2,3 Department of Environmental Engineering, Faculty of Engineering, Kasetsart University, \\ Bangkok, Thailand, Tel. (+662) 797-0999, Fax: (+662) 579-0730, email: vongsadet@ gmail.com¹, \\ fengwlc@ku.ac.th*2, fengccc@ku.ac.th ${ }^{3}$
}

Received Date: August 28, 2020; Revised Date: April 8, 2021; Acceptance Date: May 13, 2021

\begin{abstract}
This study aims to investigate the bio-augmentation of Pseudomonas putida for initializing fat, oil, and grease (FOG) biodegradation in a co-digestion of the greasy waste and the membrane bioreactor (MBR) excess sludge. The MBR sludge could be an additional nitrogen source concurrently as a waste matrix fluidizer. Three rounds of a fed-batch of an HRT of 56-71 days were carried out. The first (B1) and second (B2) batches using phosphate $\left(\mathrm{Na}_{2} \mathrm{HPO}_{4}\right)$ solution as a buffering system. It showed that the digesters with bio-augmented $P$. putida could remove more FOG than that of the control. In the third batch (B3), the buffering solution was changed to bicarbonate $\left(\mathrm{NaHCO}_{3}\right)$ with the interval bio-augmentation of $P$. putida in different doses; the 250 $\mathrm{ml}$ (B3, T-250) and the $1000 \mathrm{ml}$ (B3, T-1000) of P. putida culture every two weeks dosing. The highest FOG removal was found in both conditions with the removal efficiency of $79.77 \%$. This study suggests that bicarbonate was a suitable buffer in the co-digestion process for the interval bio-augmentation of $P$. putida. Moreover, it showed that a higher interval dose (B3, T-1000) of $P$. putida gave a more methane production rate of $981.08 \mathrm{ml} / \mathrm{g}$ TVS. $\mathrm{d}$ compared to the lower dose of B3(T-250) with $353.75 \mathrm{ml} / \mathrm{g}$ TVS. d.
\end{abstract}

Keywords: Anaerobic, Biogas, Co-digestion, Pseudomonas putida, Oil/Grease, Sludge, Waste

\section{Introduction}

Biogas is a renewable energy that promises to be a good substitution for traditional fossil fuels. Methane bio-production is a complex, multi-step process, involving many different microbial species [1,2]. Renewable energies offer an environmentally sound alternative to fossil fuels and account for a lesser contribution to climate change [1, 2]. Fats/oils/grease (FOG) waste is a common waste produced from food preparation/production by households, restaurants, schools, hospitals, and other food service facilities. FOG or greasy waste is defined as a top floatable layer of wastewater, which is high lipid content and could be separated from water by a grease trap tank. In Thailand, the grease waste-collecting from a grease trap unit has been commonly disposed of with other municipal solid wastes in landfilling. Nevertheless, the greasy waste leaking during a waste transferring process and at a transfer station create many problems, such as clogging pipes/pumping systems, interfering with an on-site wastewater treatment process [2]. Thus, greasy treatment is an alternative option for greasy waste management. Due to its characteristics particularly for high viscosity, aerobic treatment is not an appropriate option for this kind of waste. 
On the contrary, anaerobic digestion of oily waste is a potential option because the organic fatty acids from lipids hydrolysis/acidogenesis are a carbon source of methanogen. Anaerobic digestion is commonly applied for treating high organic content waste, which a preferable by-product as biogas is generated. The biogas from the typical digestion gas energy recovery systems can recover the energy required for wastewater treatment plants that use the activated sludge process $[1,2]$.

Theoretically, lipids can generate more methane than proteins and carbohydrates [3]. Methane potential yield of lipids $(1000 \mathrm{ml} / \mathrm{g} . \mathrm{VS})$, proteins $(480 \mathrm{ml} / \mathrm{g} . \mathrm{VS})$, and carbohydrate $(373 \mathrm{ml} / \mathrm{g}$.VS) has been well reported $[4,5]$. Nevertheless, in case some kind of waste in which their properties are not appropriate in anaerobic treatment process such as too high/low $\mathrm{pH}$, too high/low $\mathrm{C} / \mathrm{N}$ ratio, etc., thus a co-digestion is an optional adjustment of the waste properties of the feed. Digestion of more than one substrate in the same digester can establish positive synergism and the added nutrients can support microbial growth $[6,7]$. Different materials can enhance the anaerobic digestion process due to a better carbon and nutrient balance $[8,9,10]$. For the above reason, this study proposed the treatment of greasy waste via co-digestion of bio-solids from a wastewater treatment plant namely the membrane bioreactor (MBR) sludge.

Bio-augmentation is a strategy for process intensification and high-rate methane recovery from $\mathrm{AD}$ in industrial wastes. The typical strains used for AD are Clostridium, Acetobacterium, Enterobacter and Syntrophomonas [9, 10]. Several species in the Pseudomonas genus are facultative anaerobes (e.g., $P$. aeruginosa, $P$. fluorescens, $P$. denitrificans), suggesting that the strictly aerobic $P$. putida could be designed towards a micro-aerobic or even facultative anaerobic lifestyle with a limited number of genetic modifications. The latter has been experimentally attempted several times by engineering either anaerobic fermentation or anaerobic respiration [11].

The first attempt to create a $P$. putida strain capable of anaerobic fermentation was by Sohn et al. 2014 [12]. Moreover, Pseudomonas sp., a lipase producer, can remove such oils at the mesophilic temperature range in a short retention time; and the increase of the oil concentration and the oil type do not affect the yield [13]. Some strains of Pseudomonas putida showed a high capability in crude oil degradation [14]. Thus, it was selected as a bio-augmented microbe for initiating oil/grease biodegradation in the codigestion process in this study. The efficiency of oil/grease removal in the co-digestion of the greasy waste and the MBR sludge with and without $P$. putida bio-augmentation had been comparable. It was reported that the C: N: P ratio of Pseudomonas sp. varies between 52:8:1 to $163: 25: 1$ when $\mathrm{N}: \mathrm{P}<40: 1$ and $\mathrm{N}: \mathrm{P}>40: 1$ in culture medium, respectively [15]. Because greasy waste contains lower nutrients including phosphorus which is an essential element for microbial growth and high VFA production from lipid biodegradation could lower the $\mathrm{pH}$, thus the $\mathrm{pH}$ is a key factor in maintaining a good microbial consortium in anaerobic digestion. Therefore, additional phosphorus in form of buffer could help in $p H$ balancing and more available phosphorus source in greasy waste digestion. Alternatively, $\mathrm{NaHCO}_{3}$ is commonly used as a buffer to neutralize acid production during anaerobic digestion of refuse [16]. Thus, $\mathrm{NaHCO}_{3}$ was used as a buffer for comparison to $\mathrm{Na}_{2} \mathrm{HPO}_{4}$ in buffering capacity during the digestion. Additionally, methane production had been measured to indicate the existence of an anaerobic process of the greasy waste mixture. 


\section{Materials and Method}

\section{Experimental Set-up}

The digester was a cylindrical shape made by an acrylic material with a working volume of $0.01413 \mathrm{~m}^{3}$ and a diameter of $11.5 \mathrm{~cm}$ with a total-sizing of $0.017 \mathrm{~m}^{3}(0.22 \mathrm{~m} \mathrm{x} 0.68 \mathrm{~m} \mathrm{x}$ $0.113 \mathrm{~m})$. The gas counter was connected to the digester for counting gas production. There were 2 digesters in the experiments, the test, and the control. The mixture of two kinds of waste, the greasy waste, and the MBR sludge was employed as a feed. Both wastes were from the grease trap unit and the pilot scale-MBR unit of the cafeteria of the faculty of engineering, Kasetsart University. Generally, the greasy waste had a semi-solid form and was contaminated by a variety of small parts of food wastes. Therefore, it was blended and then analyzed for various components such as $\mathrm{pH}$, total solids, total volatile solids, oil and grease, and carbon, nitrogen before experimented with. The MBR sludge was taken from the aeration tank of the pilot-scale of membrane bioreactor and stood for 30 minutes to concentrate the sludge. Table 1 shows the chemical characteristics of each type of wastes. Then, the greasy waste was mixed with the concentrated MBR sludge at a proportion to 1:10 (v/v) to obtain approximately $\mathrm{C} / \mathrm{N}$ of the mixture waste in the range of 30-45 (Table 1).

Table 1. Average Characteristics of the Wastes (each $n=2)$

\begin{tabular}{|l|c|c|c|c|c|c|c|}
\hline \multirow{2}{*}{ Waste } & \multicolumn{7}{|c|}{ Parameters (unit \% dried weight) } \\
\cline { 2 - 8 } & $\mathbf{p H}^{\mathbf{a}}$ & TS & TVS & O\&G & $\mathbf{C}$ & $\mathbf{N}$ & C/N $^{\mathrm{a}}$ \\
\hline Greasy Waste & 5.62 & 28.40 & 92.74 & 79.84 & 79.11 & 3.04 & 26.02 \\
\hline MBR Sludge & 7.02 & 1.08 & 68.91 & 6.26 & 25.33 & 6.30 & 4.02 \\
\hline B1(C) & 7.25 & 12.68 & 80.04 & 77.82 & 54.67 & 1.55 & 35.27 \\
\hline B1 (T) & 7.24 & 9.64 & 81.37 & 76.67 & 57.13 & 1.6 & 35.71 \\
\hline B2 (C) & 7.24 & 11.92 & 86.39 & 74.93 & 53.95 & 1.27 & 42.48 \\
\hline B2 (T) & 7.25 & 9.44 & 83.07 & 74.53 & 54.00 & 1.36 & 39.71 \\
\hline B3 (T-250) & 7.25 & 10.46 & 83.15 & 88.28 & 61.42 & 1.88 & 32.67 \\
\hline B3 (T- 1000) & 7.24 & 10.69 & 81.75 & 89.13 & 62.24 & 1.54 & 40.42 \\
\hline Avg (mixture) & 7.25 & 10.81 & 82.63 & 80.23 & 57.24 & 1.53 & 37.33 \\
\hline SD (mixture) & 0.01 & 1.27 & 2.18 & 6.68 & 3.75 & 0.21 & 3.73 \\
\hline
\end{tabular}

Note: C: control; T: Test with added P. putida $1000 \mathrm{ml}$ culture initially; T-250: added 250 $\mathrm{ml}$ of $P$. putida culture every two weeks; T-1000: added $1000 \mathrm{ml}$ of $P$. putida culture every two weeks; Avg: average; SD: standard deviation; ${ }^{\text {a: }}$ unitless

After the waste loading into the digester, the anaerobic sludge from the anaerobic digester of the pig farm in Chonburi province was added into the digester as the anaerobic microbial seed at $5 \% \mathrm{v} / \mathrm{v}$, followed by the culture of $P$. putida at $5 \% \mathrm{v} / \mathrm{v}$ as the lipase producing microbe $[13,14]$. The operation was a fed-batch type, 3 rounds with different $\mathrm{pH}$ adjustment and bioaugmentation of $P$. putida (initial and interval). Two kinds of buffering systems of $\mathrm{Na}_{2} \mathrm{HPO}_{4}(\mathrm{PBS})$ and $\mathrm{NaHCO}_{3}(\mathrm{BBS})$ were employed. The $\mathrm{Na}_{2} \mathrm{HPO}_{4}$ solution was used in the $\mathrm{pH}$ adjustment of the $1^{\text {st }}(\mathrm{B} 1)$ and $2^{\text {nd }}$ (B2) batch experiment (Table 2), while the 
$3^{\text {rd }}$ batch (B3), a $\mathrm{NaHCO}_{3}$ solution was used instead. The anaerobic digestion was operated at 56-71 days of the solids retention time (SRT) per batch. It was noted that bioaugmentation of $P$. putida was performed at an initial day of B1 and B2 experiments with a $1000 \mathrm{ml}$ of culture, while that of B3 was an interval bio-augmented in every two weeks with the different doses of a $250 \mathrm{ml} \mathrm{B} 3(\mathrm{~T}-250)$ and a $1000 \mathrm{ml} \mathrm{B} 3(\mathrm{~T}-1000)$ of the culture. For B2, the remaining sludge of the B1 experiment was used as the anaerobic seed, while that of B3, the sludge of B2 was used in B3 in both digesters. Overall experimental conditions were shown in Table 2.

Table 2. Experimental Conditions

\begin{tabular}{|c|c|c|c|c|c|c|}
\hline \multirow[t]{2}{*}{ Description } & \multicolumn{3}{|c|}{ Digester 1} & \multicolumn{3}{|c|}{ Digester 2} \\
\hline & B1 (T) & B2 (T) & $\begin{array}{c}\text { B3 } \\
(\mathrm{T}-250)\end{array}$ & B1 (C) & B2 (C) & $\begin{array}{c}\text { B3 } \\
(\mathrm{T}-1000)\end{array}$ \\
\hline $\begin{array}{l}\text { Addition of } \\
P \cdot \text { putida } \\
\text { culture }^{1}\end{array}$ & $\begin{array}{c}1000 \mathrm{ml} \\
\left(\sim 2.04 \times 10^{8}\right. \\
\mathrm{CFU} / \mathrm{ml}) \\
\text { at initial day }\end{array}$ & $\begin{array}{c}1000 \mathrm{ml} \\
\left(\sim 2.04 \times 10^{8}\right. \\
\mathrm{CFU} / \mathrm{ml}) \\
\text { at initial day }\end{array}$ & $\begin{array}{c}250 \mathrm{ml}(\sim 0.51 \\
\left.\text { x } 10^{8} \mathrm{CFU} / \mathrm{ml}\right) \\
\text { every two weeks }\end{array}$ & none & none & $\begin{array}{c}1000 \mathrm{ml}(\sim 2.04 \\
\left.\mathrm{x} 10^{8} \mathrm{CFU} / \mathrm{ml}\right) \\
\text { every two } \\
\text { weeks }\end{array}$ \\
\hline $\begin{array}{l}\text { Added } P \text {. } \\
\text { putida } \\
\text { concentration } \\
\text { in digester }^{2}\end{array}$ & $\begin{array}{c}1.44 \times 10^{10} \\
\mathrm{CFU} / \mathrm{L} \\
\text { at initial day }\end{array}$ & $\begin{array}{c}1.44 \times 10^{10} \\
\mathrm{CFU} / \mathrm{L} \\
\text { at initial day }\end{array}$ & $\begin{array}{c}3.61 \times 10^{8} \\
\mathrm{CFU} / \mathrm{L} \\
\text { every two weeks }\end{array}$ & none & none & $\begin{array}{l}1.44 \times 10^{10} \\
\text { CFU/L } \\
\text { every two } \\
\text { weeks }\end{array}$ \\
\hline $\begin{array}{l}\text { Anaerobic } \\
\text { sludge seed } \\
(\mathrm{v} / \mathrm{v})\end{array}$ & $\begin{array}{c}5 \% \\
\text { (from pig } \\
\text { farm AD) }\end{array}$ & $\begin{array}{c}5 \% \text { of B1(T) } \\
\text { sludge }\end{array}$ & $\begin{array}{c}5 \% \text { of } \mathrm{B} 2(\mathrm{~T}) \\
\text { sludge }\end{array}$ & $\begin{array}{c}5 \% \\
\text { (from pig } \\
\text { farm AD) }\end{array}$ & $\begin{array}{l}5 \% \text { of } \\
\text { B1(C) } \\
\text { sludge }\end{array}$ & $\begin{array}{c}5 \% \text { of } \mathrm{B} 2(\mathrm{~T}) \\
\text { sludge }\end{array}$ \\
\hline $\begin{array}{l}\text { Buffer } \\
\text { solution }\end{array}$ & PBS & PBS & BBS & PBS & PBS & BBS \\
\hline SRT, days & 63 & 63 & 71 & 71 & 56 & 56 \\
\hline
\end{tabular}

Note: C: control; T: Test; PBS: $\mathrm{Na}_{2} \mathrm{HPO}_{4}$; $\mathrm{BBS}$ : $\mathrm{NaHCO}_{3}$; the $P$. putida addition in form of concentrated cells after centrifugation; ${ }^{1}$ : the concentration of $P$. putida as described in [17]; ${ }^{2}$ : the calculated concentration of P. putida as Equation 1.

\section{Chemicals for Buffering System}

Generally, the greasy waste contains high carbon but lower macro-nutrients ( $\mathrm{N}$ and $\mathrm{P}$ ) for microbial growth. Because phosphorus is an essential element in bacterial growth [15], therefore, additional phosphorus in form of buffer could help in $\mathrm{pH}$ balance and more available phosphorus in microbial greasy waste digestion. In the study, $\mathrm{Na}_{2} \mathrm{HPO}_{4}$ (PBS) was selected as a buffer, and additional phosphorus available in the digestion process in $\mathrm{B} 1$ and $\mathrm{B} 2$ experiments. The $\mathrm{pH}$ of the disodium hydrogen phosphate water solution is commonly between 8.0-11.0. While the bicarbonate $\left(\mathrm{NaHCO}_{3}, \mathrm{BBS}\right)$, a common buffer for anaerobic digestion [16], was used in the B3 experiment to compare capability in acidity tolerance. Both chemicals were prepared at $5 \% \mathrm{w} / \mathrm{v}$ for buffer solution. The buffer was added to the waste mixture to adjust the $\mathrm{pH}$ of 7.0 initially. It is noted that a mediated partial suppression of methanogenesis and acetogenesis with cation toxicity when the too high concentration of $\mathrm{NaHCO}_{3}$ was applied > 5\% [16]. 


\section{Culture of Pseudomonas Putida}

Pseudomonas putida, a member of the genus Pseudomonas described is a Gram-negative, non-spore-forming, straight, or slightly curved rods bacterium. It is a fast-growing bacterium found in most temperate soil and water habitats. It grows optimally at $25-30{ }^{\circ} \mathrm{C}$ and can be easily cultured in the laboratory. This study, the pure culture, $P$. putida (TISTR 1522) was ordered from the Thailand Institute of Scientific and Technological Research. Tryptic Soy Agar (TSA) is a universal medium that supports the growth of $P$. putida (TISTR 1522). It was cultured on TSA and incubated overnight at $25-30{ }^{\circ} \mathrm{C}, 14 \mathrm{~h}$ according to a description in the TISTR leaflet. Then, the isolate was grown in $1 \mathrm{~L}$ of Tryptic Soy Broth (TSB) to obtain the $P$. putida biomass of 1.0 at OD600 (approximately equivalent to $2.04 \times 10^{8} \mathrm{CFU} / \mathrm{ml}$ [17]). Then, the biomass suspension was centrifuged at 7,000 rpm at $4{ }^{\circ} \mathrm{C}, 10 \mathrm{~min}$. Thereafter, the cells were washed with a sterile sodium chloride solution $(\mathrm{NaCl})(0.85 \% \mathrm{w} / \mathrm{v}) 3$ times to ensure that the adsorbed culture medium on cells was almost removed. For bioaugmentation, the culture precipitate was re-suspended in a $10 \mathrm{ml}$ saline solution. Then, the $10 \mathrm{ml}$ of cell suspension was added into the digester at the initial/interval time of the experiments as described in Table 2. The $P$. putida concentration of the waste mixture in each condition was calculated as shown in Equation 1. All calculated concentrations of $P$. putida of each digester condition are shown in Table 2.

The concentration of $P$. putida in the waste

$$
=\text { P. putida concentration, } \mathrm{CFU} / \mathrm{ml} \text { x Media culture volume, } \mathrm{ml}
$$

A total volume of the waste in a digester, $\mathrm{L}$

\section{Analytical Methods}

All basic parameters were determined according to standard methods [18]. Total solids and total volatile solids of the waste samples were determined using a digital weighing after drying the waste sample at $105^{\circ} \mathrm{C}$ and $600^{\circ} \mathrm{C}$, respectively. The $\mathrm{pH}$ measurement of the waste samples was done using a $\mathrm{pH}$ meter and a $\mathrm{pH}$ indicator strip (non-bleeding) $\left(\right.$ Merck $\left.{ }^{\circledR}\right)$ for the MBR sludge/waste mixture and the greasy waste, respectively. The $\mathrm{pH}$ of the waste in the digester was recorded weekly. Oil and grease were analyzed by the Soxhlet extraction method in duplicate per sample. Finally, biogas production was recorded every day. Methane concentration was determined by gas chromatography (6890 Series, Agilent). The carbon and nitrogen contents of the waste were analyzed by CHNS/O analyzer (PerkinElmer 2400).

\section{Results and Discussion}

\section{Effects of Buffering System on pH Changes}

Generally, a buffering system is required to maintain $\mathrm{pH}$ value within the desired range suitable for the methanogenic process because continual volatile fatty acids production during acidogenesis will lower the $\mathrm{pH}$ level of the waste matrix. A well-buffered anaerobic digester means the ability to provide resistance to significant and rapid changes in $\mathrm{pH}$ when the acidic compounds accumulated in digesters [19] of which $\mathrm{pH}<6.5$ can inhibit methanogenic activity. Acidification during anaerobic digestion due to organic overloading is one of the major reasons for process failures and decreased methane productivity in anaerobic digesters [20]. In this study, the first and second batch experiments using $\mathrm{Na}_{2} \mathrm{HPO}_{4}$ 
as a buffering system. It showed that $\mathrm{pH}$ had gradually decreased within 7 weeks of operation in both digesters of which the B1(T) and B2(T)-digesters with $P$. putida had a slightly lower $\mathrm{pH}$ level relative to $\mathrm{B} 1(\mathrm{C})$ and $\mathrm{B} 2(\mathrm{C})$-digesters in the B1 and B2 experiments (Figure 1). Nevertheless, a sharp drop of $\mathrm{pH}$ of T-digesters was observed at day 63 of operation in both batches. The lower $\mathrm{pH}$ levels in the anaerobic digester indicate more VFA production which was the by-product of organic waste degradation of acidogenic bacteria [19]. More acid compounds produced in the T-digesters were possibly influenced by $P$. putida addition. The last two weeks of operation had $\mathrm{pH}$ levels $<6.5$, which is a general critical point for methanogenic activity [21]. Acid crisis characterized by acid accumulation and/or low $\mathrm{pH}$ is a common reason for the failure of anaerobic digestion (AD), which is usually applied for wastewater and waste treatment [21]. This suggests that PBS might not be enough buffering capacity for FOG digestion, particularly a longer SRT >56 days operation. When a buffering system was changed to BBS in the B3 experiment. The $\mathrm{pH}$ of day 56 was slightly higher than the previous batches (B1 and B2) as of 6.68 and 6.63 for B3(T250) and B3(T-1000) digesters, respectively (Figure 1). It suggests that BBS buffer had better-buffering capacity than PBS buffer. This might be because the carbon dioxide production during B3 digestion could be additional carbonate-bicarbonate levels in the buffering system.

Additionally, the determination of volatile fatty acids and alkalinity concentration and its ratio had been carried out during the B3 experimental period (Table 3). It shows that the initial FOG waste had $\mathrm{pH}$ 7.1-7.2 with the VFA/ALK ratios of 1.33 and 1.22 for B3(T-250) and B3(T-1000), respectively. During B3 digestion, VFA as $\mathrm{CH}_{3} \mathrm{COOH}$ in both conditions had increased gradually with time. The B3(T-1000) showed slightly higher VFA contents (620 to $990 \mathrm{mg} / \mathrm{L}$ as $\mathrm{CH}_{3} \mathrm{COOH}$ ) than that of $\mathrm{B} 3(\mathrm{~T}-250)$ as of 560 to $980 \mathrm{mg} / \mathrm{L}$ as $\left.\mathrm{CH}_{3} \mathrm{COOH}\right)$. Similarly, alkalinity contents had increased with time as a result of more available bicarbonate in both digesters due to more biogas production (Figure 4 and 5). Higher alkalinity content of B3(T-1000) condition was found. As a result, its VFA/ALK ratio was lower. It reported that the VFA proper value should be not more than 2,000 mg/L as $\mathrm{CH}_{3} \mathrm{COOH}$ [16], while alkalinity prefers $2,500-5,000 \mathrm{mg} / \mathrm{L}$ for AD operation [22].

Table 3. Average Volatile Fatty Acids, Alkalinity and VFA/ALK Ratio during B3 Experiment

\begin{tabular}{|c|c|c|c|c|c|c|}
\hline \multirow[t]{2}{*}{ Days } & \multicolumn{2}{|c|}{$\begin{array}{c}\text { VFA } \\
\left(\mathrm{mg} / \mathrm{L} \text { as } \mathrm{CH}_{3} \mathrm{COOH}\right)\end{array}$} & \multicolumn{2}{|c|}{$\begin{array}{c}\text { ALK } \\
(\mathrm{mg} / \mathrm{L} \text { as } \mathrm{CaCO3})\end{array}$} & \multicolumn{2}{|c|}{ VFA/ALK ratio } \\
\hline & B3(T-250) & B3(T-1000) & B3(T-250) & B3(T-1000) & B3(T-250) & B3(T-1000) \\
\hline 0 & 560 & 620 & 420 & 510 & 1.33 & 1.22 \\
\hline 7 & 600 & 660 & 620 & 620 & 0.97 & 1.06 \\
\hline 14 & 650 & 690 & 680 & 750 & 0.96 & 0.92 \\
\hline 21 & 730 & 720 & 960 & 910 & 0.76 & 0.79 \\
\hline 28 & 790 & 810 & 1140 & 920 & 0.69 & 0.88 \\
\hline 35 & 840 & 870 & 1190 & 1040 & 0.71 & 0.84 \\
\hline 42 & 910 & 900 & 1390 & 1490 & 0.65 & 0.60 \\
\hline 49 & 960 & 940 & 1520 & 1730 & 0.63 & 0.54 \\
\hline 56 & 980 & 990 & 1610 & 1910 & 0.61 & 0.52 \\
\hline
\end{tabular}

Note: B3(T-250): $250 \mathrm{ml}$ of P. putida culture was added every two weeks; B3(T-1000): 1000 $\mathrm{ml}$ of $P$. putida culture was added every two weeks 


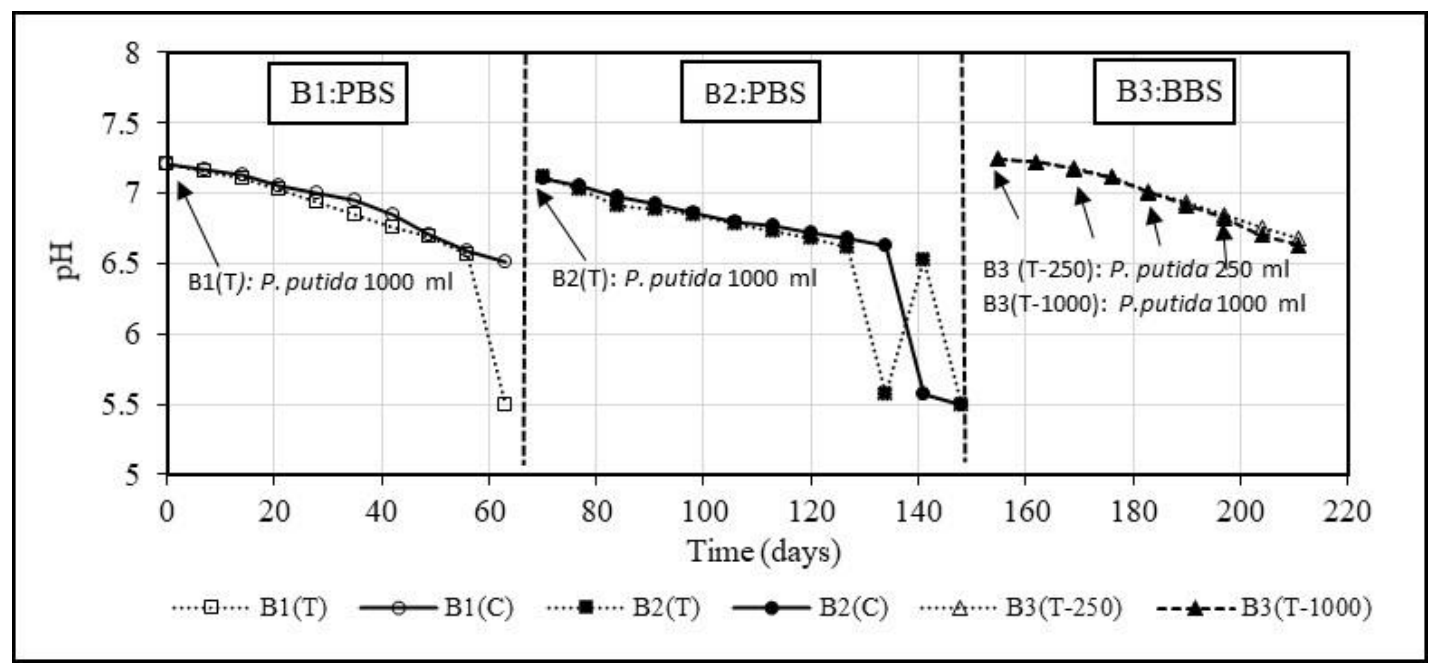

Figure 1. $\mathrm{pH}$ changes during digestion (Arrows indicate day of $P$. putida addition)

Note: B1(T) \& B2 (T): $1000 \mathrm{ml}$ of $P$. putida added; B1(C) \& B2 (C): None of P. putida; B3 (T-250): $250 \mathrm{ml}$ of $P$. putida added per two weeks; B3 (T-1000): $1000 \mathrm{ml}$ of P. putida added per two weeks

\section{Removal of Fat, Oil, and Grease (FOG)}

Figure 2 shows the removal of FOG in all operational conditions of the co-digestion system. The FOG removal efficiency between the test digester and the control digester in the B1 experiment was different after 20 days of operation. Within 63 days of operation, only $17.72 \%$ FOG removal was found in the control digester, while that of the test digester was higher as of $31.64 \%$. It suggests that $P$. putida addition to the co-digestion process could promote more lipid hydrolysis. The FOG removal of the digesters in the B2 experiment showed the same trend as of B1 experiment but better removal efficiencies were shown. The oil content of the control digester gradually decreased by giving $21.5 \%$ removal, while that of $46.83 \%$ in the test digester appearing after 63 days of digestion. This is because the remained digested sludge of the B1 digester might contain the acclimatized microbes of FOG biodegradability. Thus, more biodegradation of FOG was found in the B2 experiment. The decreasing $\mathrm{pH}$ level (Figure1) was corresponding well with the decreasing FOG contents in both digesters (Figure 2). Similarly, a previous study reported the utilization of grease waste by Psueomonas chrysogenum SNP5, one of the lipase producers, suggesting that it can be used for grease remediation [20].

In the B3 experiment, B3(T-250) and B3(T-1000) (added P. putida+BBS), sharply decreased FOG content in both digesters were found in the first week of operation. This was possible that both digesters had acclimatized anaerobic microbial consortium including $P$. putida (5\% v/v of B2(T) sludge, Table 2). Additionally, FOG content in B3(T-250) had decreased faster than that of $\mathrm{B} 2(\mathrm{~T})$ digester even equivalent dose of $P$. putida per batch. It suggests that interval addition of $P$. putida was better than adding in once. Moreover, the FOG content of B3(T-1000) decreased faster than that of B3(T-250) during week 1 to 3 of the digestion period. It indicates that a higher dose of $P$. putida could enhance more FOG biodeterioration. Nevertheless, the final FOG removal showed no differences between both conditions by giving similarly the highest of $79.77 \%$ FOG removal. This might involve the balance of VFA/Alk ratio, caused by faster VFA production of B3(T-1000) (Table 3) during 
21 days digestion gave negative effect on lipid degradation rate [23]. Because gradually decreasing $\mathrm{pH}$ levels in both digesters were observed throughout the experimental period (Figure 1), thus it suggests that bicarbonate was a good buffering capacity even the FOG removal in the B3 experiment was very fast relative to B1/B2 experiments which using PBS as the buffer. Finally, it concludes that the interval bio-augmentation of $P$. putida gave better efficiency in FOG removal relative to a single dose at an initial day while the dose of $P$. putida was not much influence on FOG removal. According to $\mathrm{pH}$ controlling and FOG removal, bio-augmentation of $P$. putida $\left(3.61 \times 10^{8} \mathrm{CFU} / \mathrm{L}\right.$, Table 2$)$, every two weeks using bicarbonate buffer is recommended for the operation of the co-digestion of greasy waste with the MBR sludge for high FOG removal efficiency.

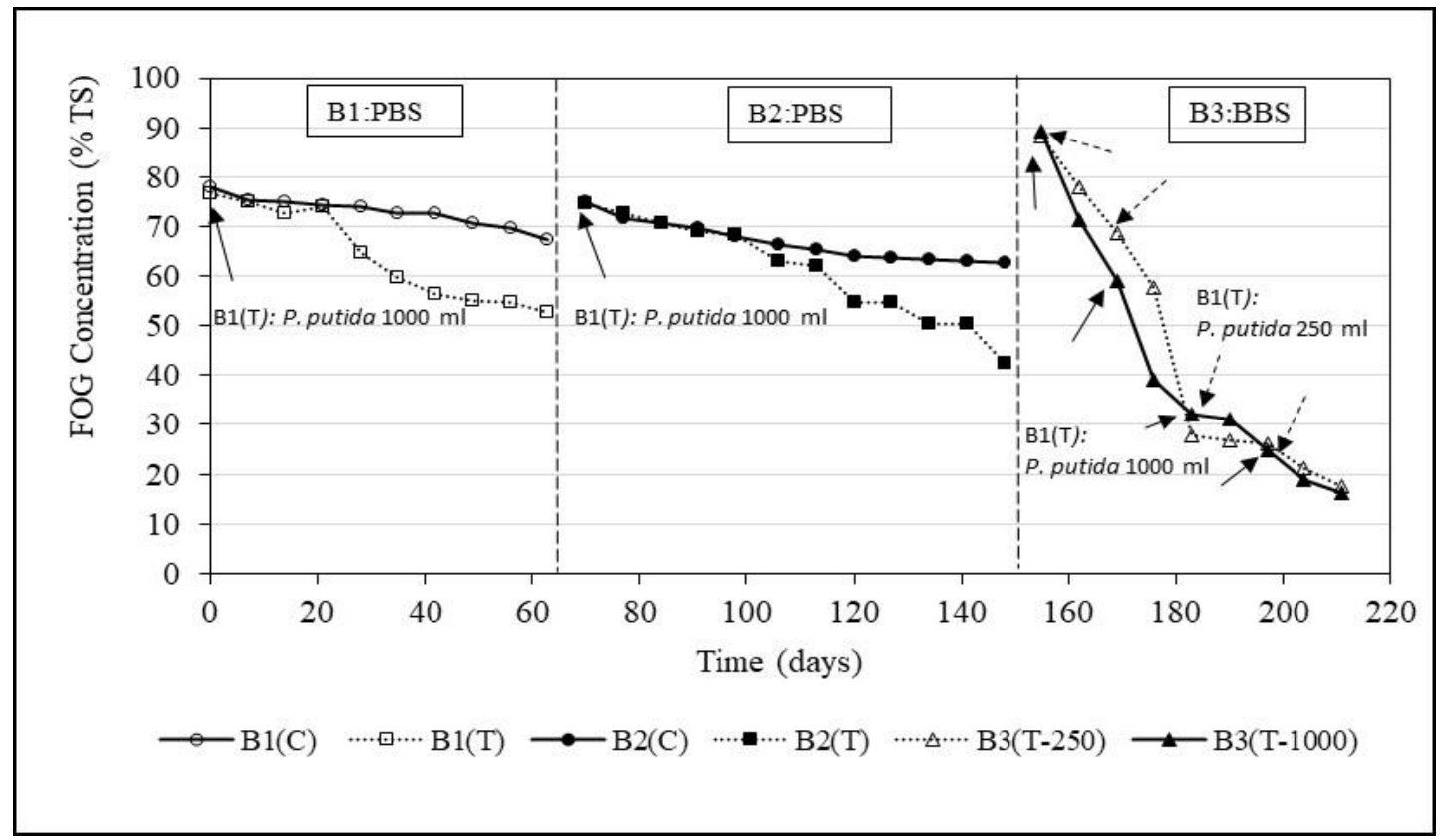

Figure 2. Changes of FOG content during digestion under different buffering system (Arrows indicate day of $P$. putida culture addition)

Note: B1(T) \& B2 (T): $1000 \mathrm{ml}$ of $P$. putida added; B1(C) \& B2 (C): None of $P$. putida; B3 (T-250): $250 \mathrm{ml}$ of $P$. putida added per two weeks; B3 (T-1000): $1000 \mathrm{ml}$ of $P$. putida added per two weeks.

\section{Removals of Total Solids and Total Volatile Solids}

In this experiment, total solids and volatile solids were analyzed every week (Figure 3). It was found that total solids (TS) and total volatile solids (TVS) in the control digesters decreased faster in B1(C) during 20 days of the operation period, thereafter they showed gradually decreased until the end of the operation. Similarly, B2(T) showed decreasing trends as B1(T) both TS and TVS which lower remaining fraction compared to the control (B2(C)). It suggests that $P$. putida addition could promote organic matter (TVS) degradation in the co-digestion process. The TVS reduction was corresponding well with the results of FOG removal (Figure 2). Thus, it suggests that the removed TVS in the system was mainly in a form of FOG. Nevertheless, in the B3 experiment, lower TVS fractions were found for B3(T-250), while \%FOG content was equal to B3(T-1000). It suggests that other forms of organic matter in B3(T-250) could be degraded concurrently with FOG. Alternatively, too high the addition of $P$. putida might result in more variety of VFA species. The severity of 
long-chain fatty acids (LCFA) toxicity to microorganisms in AD is also thought to increase in the presence of a mixture of LCFAs rather than a single LCFA [2]. As a result, it might give unpreferable conditions to other microbial consortiums involving in other organic matters biodegradation.

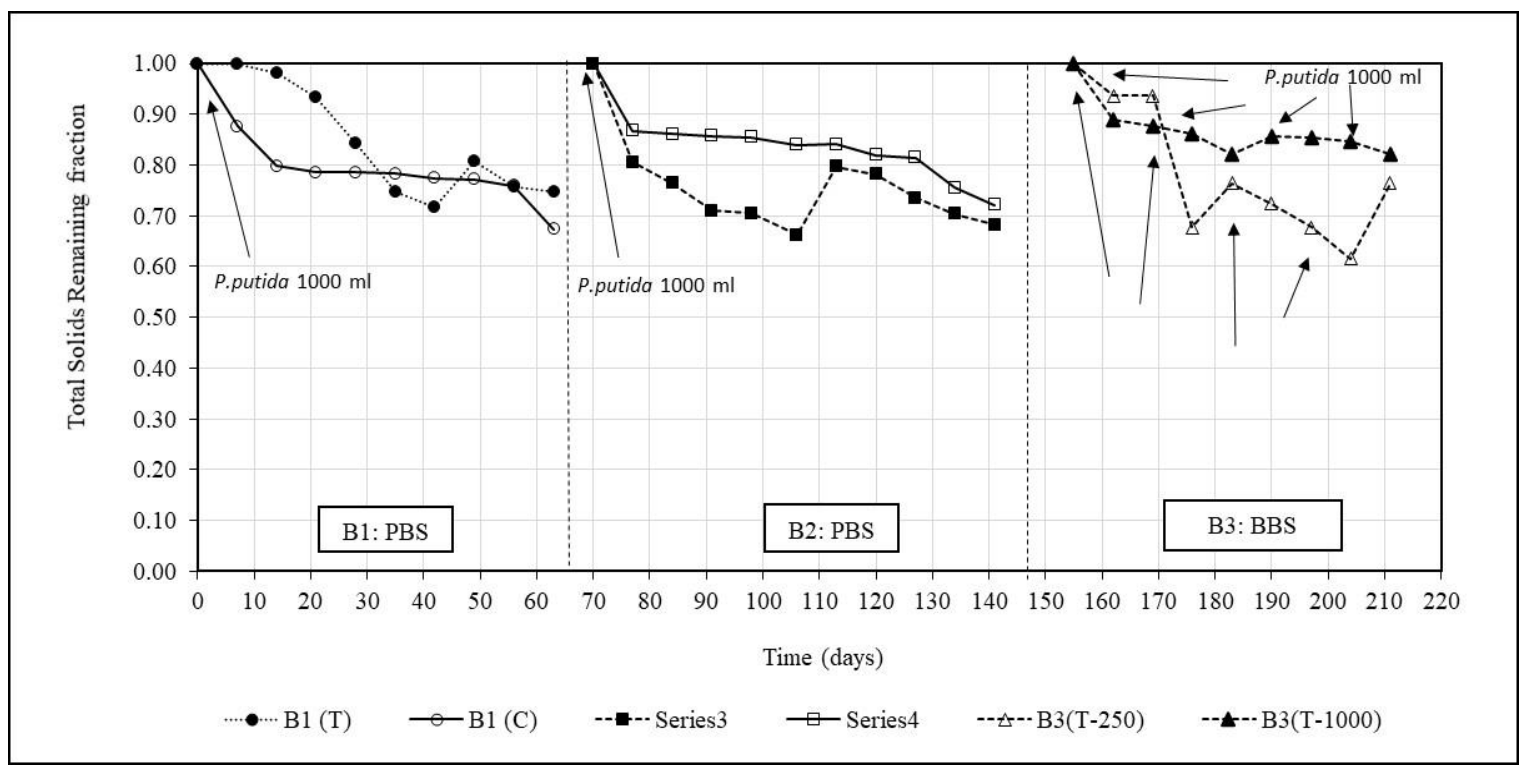

(a)

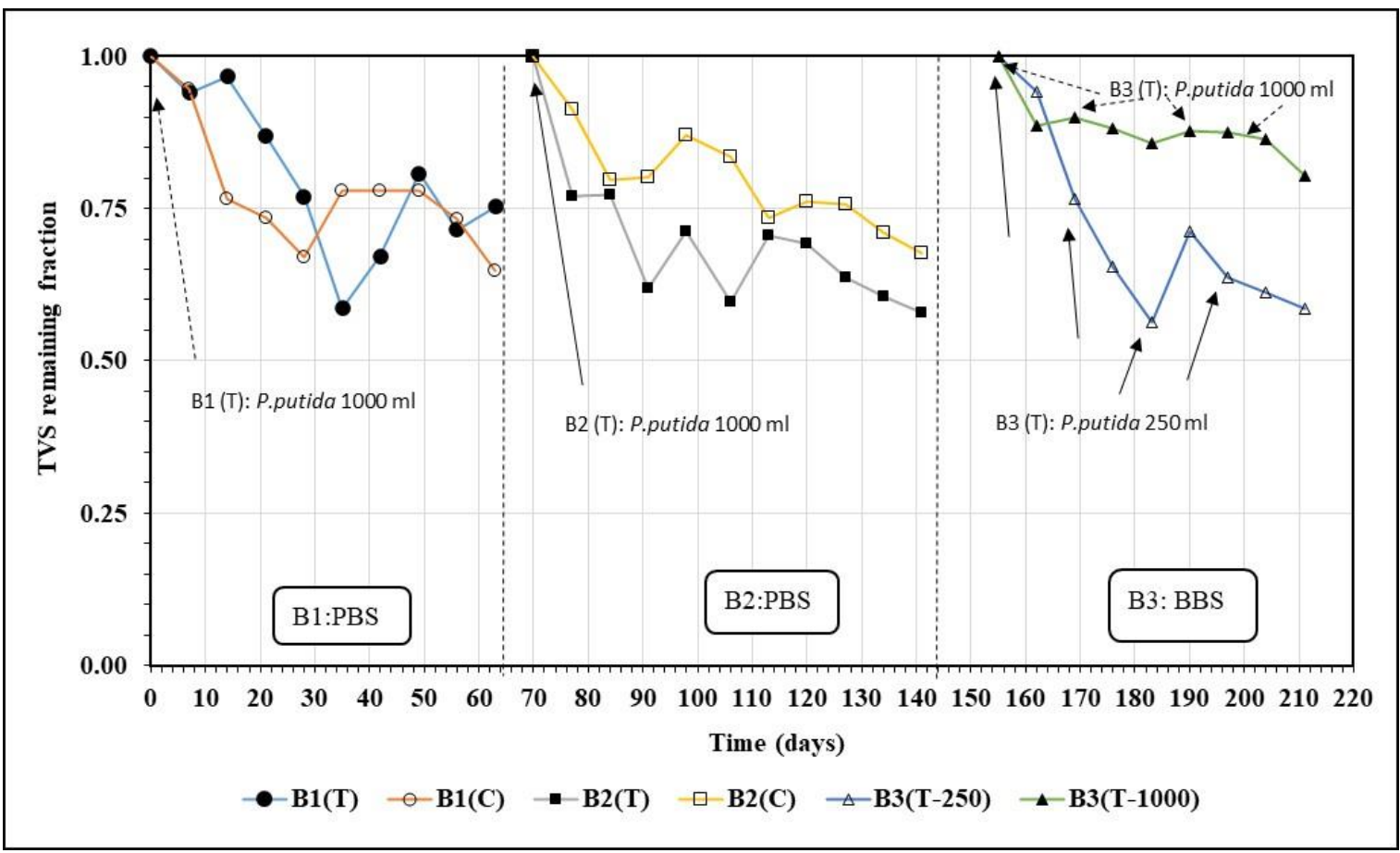

(b)

Figure 3. Changes of TS (a) and TVS (b) remaining fractions during digestion under different buffering system (Arrows indicate day of $P$. putida culture addition)

Note: B1(T) \& B2 (T): $1000 \mathrm{ml}$ of $P$. putida added; B1(C) \& B2 (C): None of P. putida; B3 (T-250): $250 \mathrm{ml}$ of $P$. putida added per two weeks; B3 (T-1000): $1000 \mathrm{ml}$ of $P$. putida added per two weeks. 


\section{Biogas Production}

Biogas is a mixture of various types of gas, including $\mathrm{CH}_{4}, \mathrm{CO}_{2}, \mathrm{~N}_{2}$, and $\mathrm{H}_{2} \mathrm{~S}$ [22]. The biogas production in all test batches is shown in Figure 4 to Figure 5. The results showed that there was not much difference in accumulative biogas production (5.9-6.0 L) between with or without $P$. putida condition at the end of the B1 and B2 experiments (Figure 4), but lower production as compared to that of the B3 experiment (Figure 5). Nevertheless, the gas production rate per day of $\mathrm{B} 3$ in both conditions (B3(T-250) and $\mathrm{B} 3(\mathrm{~T}-1000)$ showed a higher rate $\sim 0.5$ to $0.3 \mathrm{~L} / \mathrm{d}$ than that of $\mathrm{B} 1$ and $\mathrm{B} 2(<0.05 \mathrm{~L} / \mathrm{d})$. It is corresponding well with the FOG removals in both conditions. It supports that the FOG biodegraded products were finally bio-transformed to biogas in the co-digestion condition.

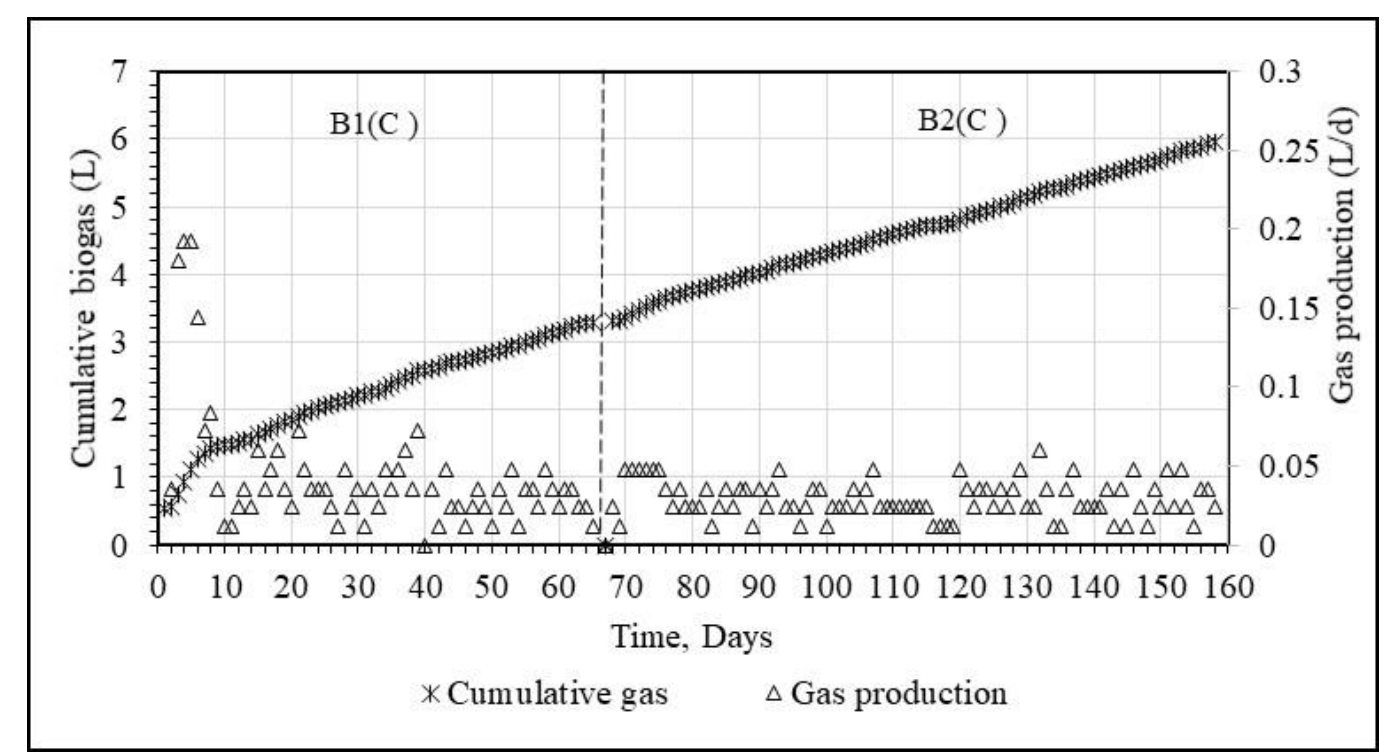

(a)

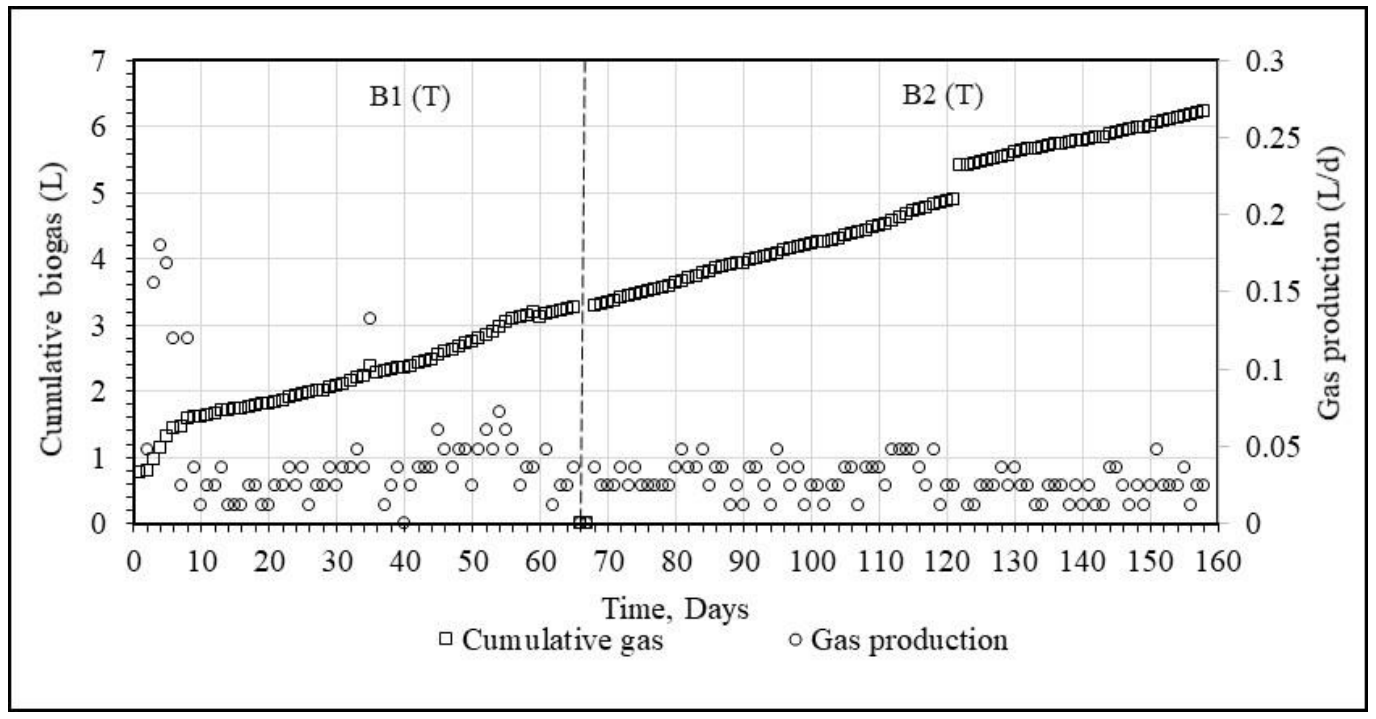

(b)

Figure 4. Biogas production in B1, B2 digesters

Note: B1(T) \& B2 (T): $1000 \mathrm{ml}$ of $P$. putida added at initial day; B1(C) \& B2 (C): None of $P$. putida addition. 


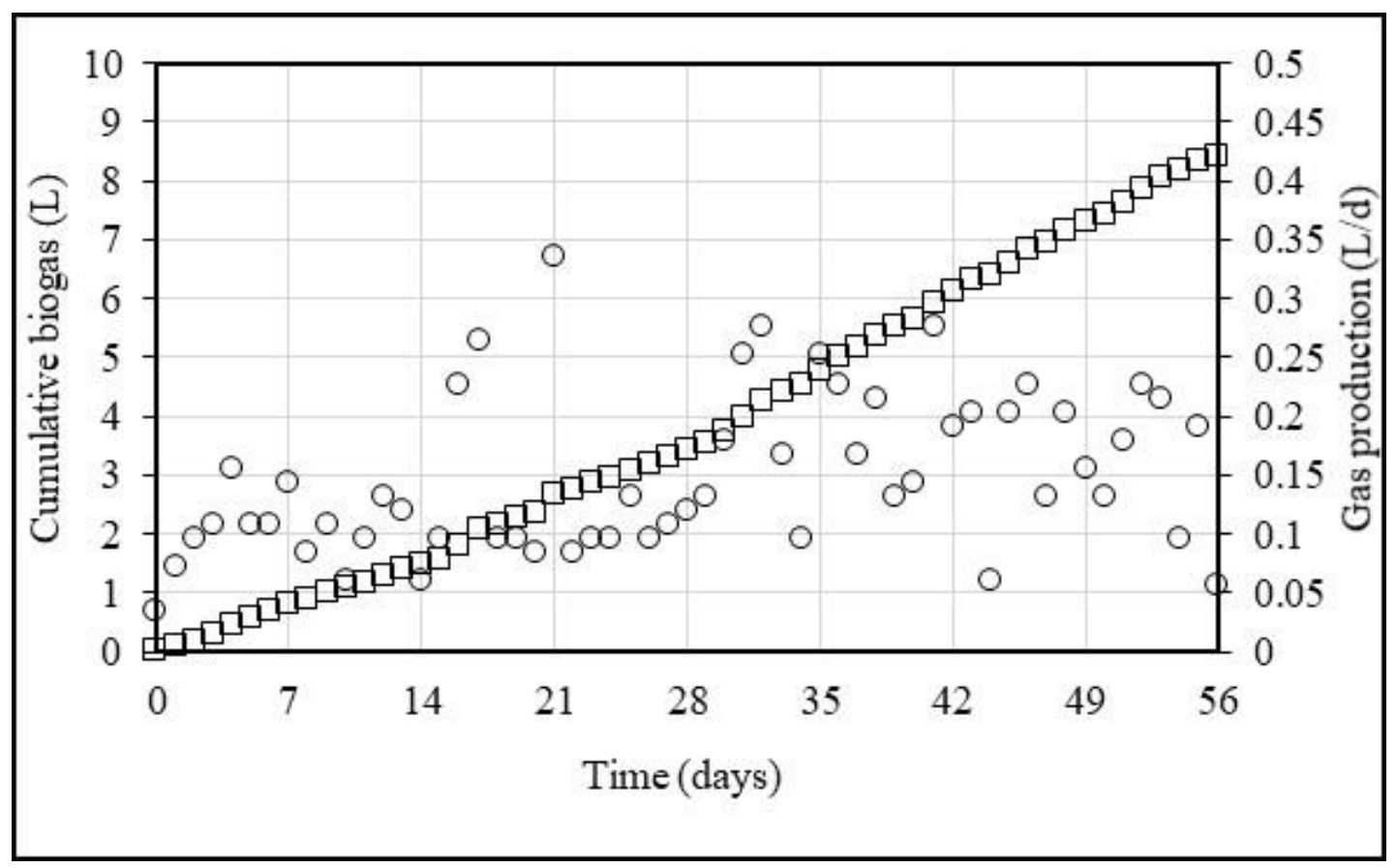

(a)

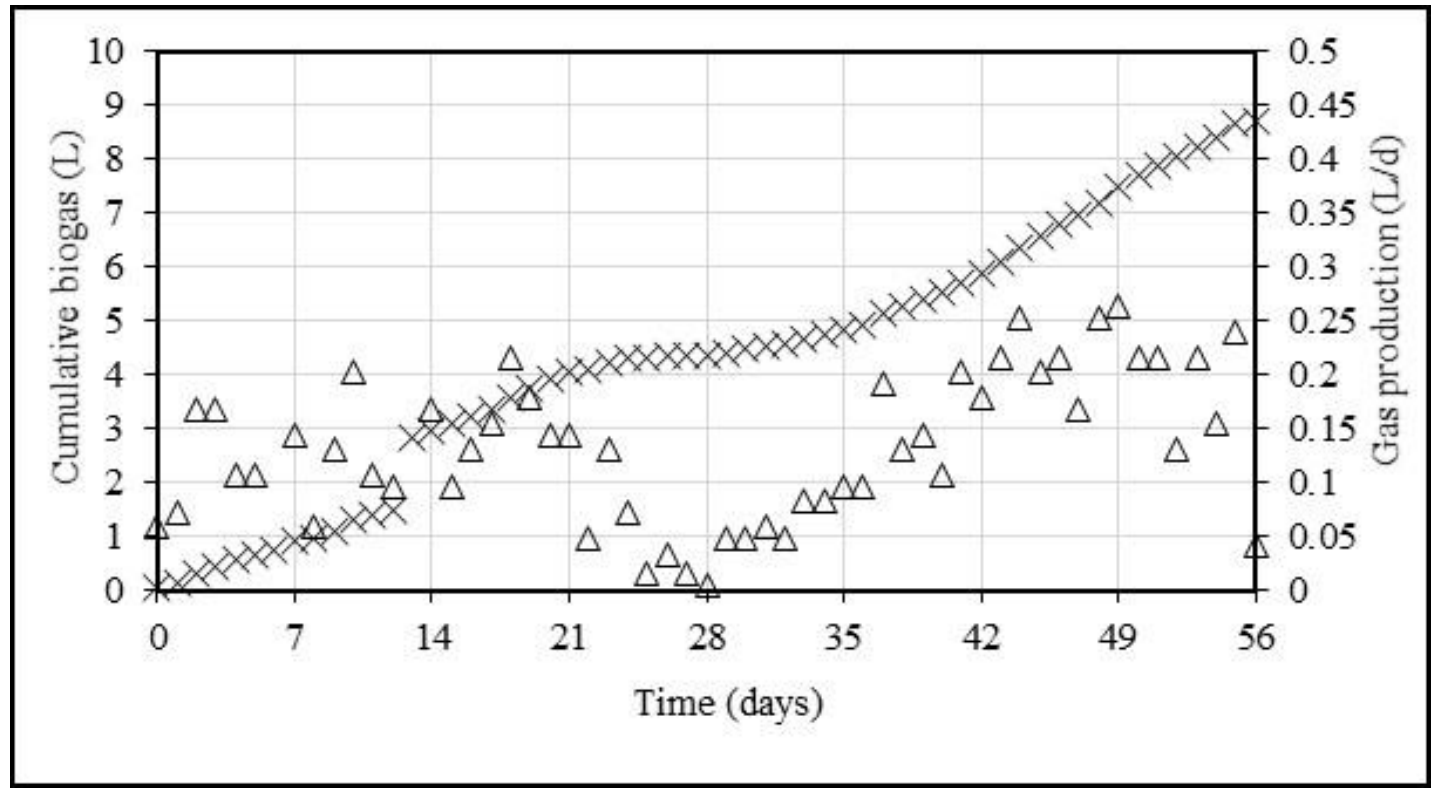

(b)

Figure 5. Gas production in B3(T-250); square: cumulative gas; circle: gas production (a) and $\mathrm{B} 3(\mathrm{~T}-1000)$; cross: cumulative gas; triangle: gas production (b)

Note: B3 (T-250): $250 \mathrm{ml}$ of $P$. putida added every two weeks; B3 (T-1000): $1000 \mathrm{ml}$ of $P$. putida added every two weeks.

\section{Changes in Methane Concentration and Production Rates}

In B1experiment, methane concentration gradually increased with time which corresponding to the decreasing of FOG content. After 30 days of operation, the methane concentration in the test digester was higher than that of the control digester. However, the methane concentration of methane reached the same level $(25 \%)$ at 63 days of operation in both digesters. When the waste mixture was fed in the $\mathrm{B} 2$ experiment, methane concentration was 
continually increasing up to $35 \%$ at 148 days of operation (Figure 6). It showed that the methane concentration started at a high level of $30 \%$ in both digesters. As mentioned above, there was the acclimatized sludge remaining from the B1 experiment used as the additional seed for the B2 start-up. Thus, the methane concentration of the test digester was higher than that of the control in some weeks but it was no significant difference in methane concentration at the end of operation which indicates no interference of $P$. putida addition on methanogenic activity. When a buffer solution was changed to bicarbonate, the methane concentration of $\mathrm{B} 3(\mathrm{~T}-1000)$ was about $58 \%$ which was higher than that of $\mathrm{B} 3(\mathrm{~T}-250)$ on the last day of operation. Because the FOG content was continually removed after 20 days of operation, it suggests that methane-producing in the B3 experiment might be from FOG degradation rather than the bio-solids degradation of the MBR sludge. Table 4 shows the methane production rate in each condition compared to previous studies. It is seen that the methane production rate in the digester with $P$. putida addition had a higher production rate. The highest production was found in B3(T-1000) with $961.08 \mathrm{ml} / \mathrm{g}$ TVS. d equivalent to $202.95 \mathrm{ml} / \mathrm{g}$ FOG. $\mathrm{d}$. This value is higher than the reports of previous studies with a variety of mixture of FOG with various types of wastes such as thickening sludge of WWTP, sewage sludge, sedimentation tank sludge with the production rate of methane of 159 to $681 \mathrm{ml} / \mathrm{g}$ VS added, [23, 24, 25, 26]. This result suggests that a higher dose of $P$. putida, B3(T-1000), gave more methane production than that of the lower dose of $P$. putida (B3, T-250). It suggests that more $P$. putida concentration could better enhance methane formation in this co-digestion system. Alternatively, considering the cost of the operation, the $250 \mathrm{~mL}$ of $P$. putida addition every two weeks is more interesting in terms of equivalent FOG removal as the higher dose condition. Nevertheless, a lower methane production rate $(353.75 \mathrm{ml} / \mathrm{g} \mathrm{TVS}$. d) was found in B3(T-250) compared to the higher dose (B3(T-1000)).

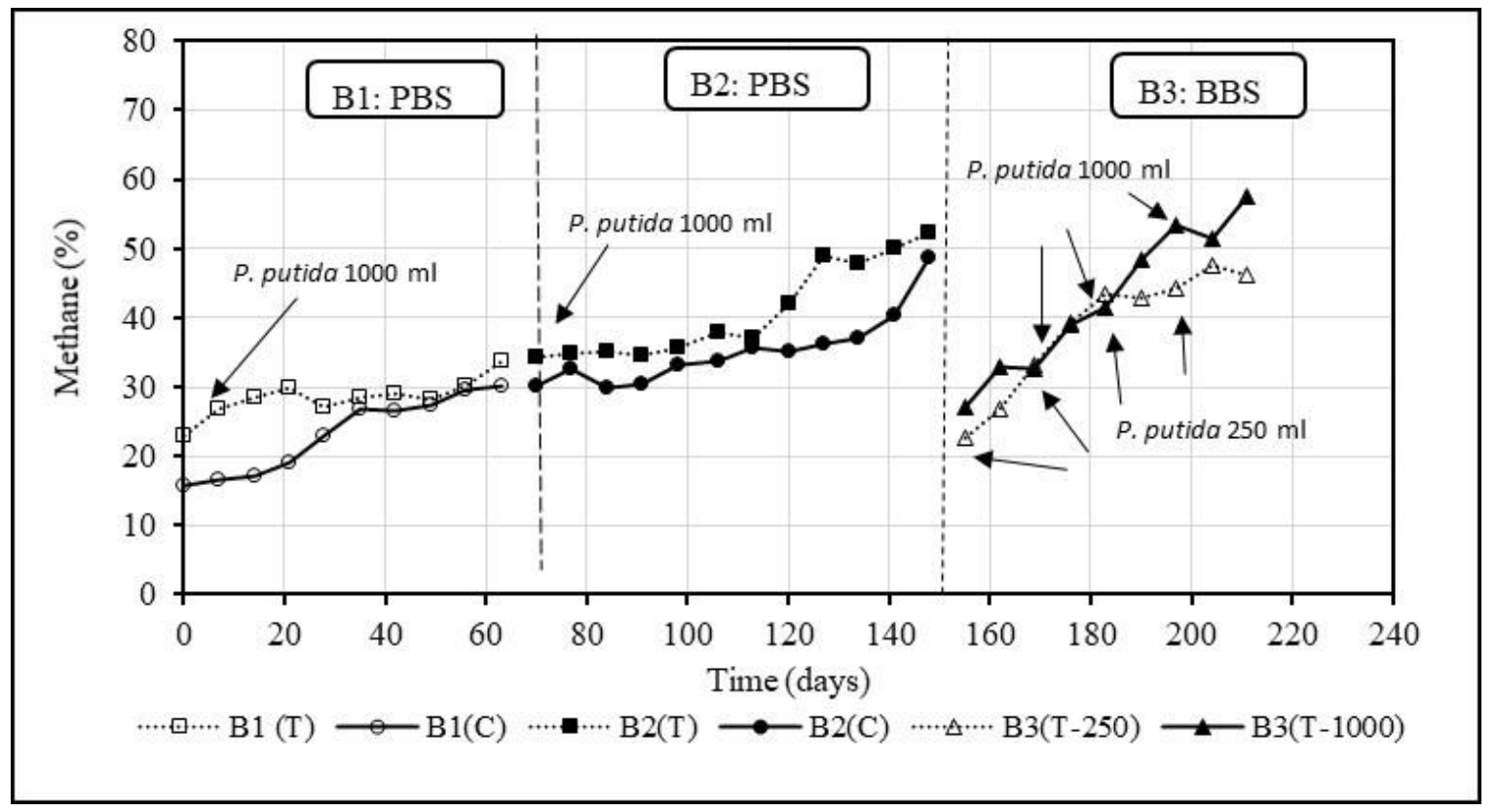

Figure 6. Changes of methane concentration in the digesters using $\mathrm{PHB}$ and $\mathrm{NaHCO}_{3}$ as a buffering solution (Arrows indicate the addition of $P$. putida)

Note: B1(T) \& B2 (T): $1000 \mathrm{ml}$ of $P$. putida added; B1(C) \& B2 (C): None of P. putida; B3 (T-250): $250 \mathrm{ml}$ of $P$. putida added per two weeks; B3 (T-1000): $1000 \mathrm{ml}$ of $P$. putida added per two weeks. 
Table 4. Methane Yield in Each Condition

\begin{tabular}{|l|c|c|c|l|}
\hline \multicolumn{1}{|c|}{ Conditions } & $\begin{array}{c}\mathbf{C H}_{4} \\
\text { (ml/g TS. d) }\end{array}$ & $\begin{array}{c}\mathbf{C H}_{4} \\
\text { (ml/g TVS. d) }\end{array}$ & $\begin{array}{c}\mathbf{C H}_{4} \\
\text { (ml/g FOG. d) }\end{array}$ & Reference \\
\hline B1(T) with SRT 63 day & 181.79 & 189.42 & 108.67 & This study \\
\hline B1(C) with SRT 63 day & 84.67 & 102.23 & 86.51 & This study \\
\hline B2(T) with SRT 71 day & 216.04 & 196.92 & 170.58 & This study \\
\hline B2(C) with SRT 71 day & 123.49 & 163.33 & 128.98 & This study \\
\hline $\begin{array}{l}\text { B3(T-250) with SRT 56 } \\
\text { day }\end{array}$ & 296.02 & 353.75 & 156.02 & This study \\
\hline $\begin{array}{l}\text { B3(T-1000) with SRT 56 } \\
\text { day }\end{array}$ & 848.11 & 961.08 & 202.95 & This study \\
\hline $\begin{array}{l}\text { Sewage thickening sludge } \\
\text { +FOG In two phase CSTR } \\
\text { with SRT 13 days }\end{array}$ & - & $\begin{array}{c}159-551 \mathrm{ml} \\
\text { biogas/g VS } \\
\text { added }\end{array}$ & - & {$[23]$} \\
\hline $\begin{array}{l}\text { WWTP sludge +grease } \\
\text { trap sludge in methane } \\
\text { potential reactor }\end{array}$ & - & $\begin{array}{c}325-681 \mathrm{ml} \\
\mathrm{CH}_{4} / \mathrm{g} \text { VS added }\end{array}$ & - & {$[24]$} \\
\hline $\begin{array}{l}\text { WWTP sludge +grease } \\
\text { trap sludge in batch fed } \\
\text { once per day with SRT 10- } \\
\text { 13 days }\end{array}$ & - & $\begin{array}{c}271-344 \mathrm{ml} \\
\mathrm{CH}_{4} / \mathrm{g} \text { VS added }\end{array}$ & - & {$[25]$} \\
\hline $\begin{array}{l}\text { WWTP sludge +grease } \\
\text { trap sludge in CSTR with } \\
\text { SRT 16 days }\end{array}$ & & $\begin{array}{c}278-463 \mathrm{ml} \\
\mathrm{CH}_{4} / \mathrm{g} \text { VS added }\end{array}$ & & \\
\hline
\end{tabular}

Note: The calculation of methane yield based on $\% \mathrm{CH} 4$ of the last day operation and cumulative methane; conditions: B1(T) \& B2 (T): $1000 \mathrm{ml}$ of P. putida added; B1(C) \& B2 (C): None of P. putida; B3 (T-250): $250 \mathrm{ml}$ of $P$. putida added per two weeks; B3 (T-1000): $1000 \mathrm{ml}$ of $P$. putida added per two weeks; CSTR: Continuously stirred tank reactor.

\section{Conclusions}

A bio-augmentation of $P$. putida showed better efficiency in the removal of FOG contents in the anaerobic co-digestion of greasy waste and the membrane bioreactor (MBR) excess sludge. However, there was no difference in FOG removal between the low and high dose of $P$. putida, while the interval bioaugmentation gave faster FOG biodegradation than a single dose initially. The co-digestion using bicarbonate as a buffering system showed better $\mathrm{pH}$ controlling than phosphate buffer. Nevertheless, interval P. putida augmentation with a higher dose gave more methane production rate. According to $\mathrm{pH}$ controlling and FOG removal, $P$. putida bio-augmentation at $250 \mathrm{ml}$ every two weeks using bicarbonate as a buffer is suggested as the operational condition of the co-digestion of greasy waste and the MBR sludge.

\section{Acknowledgments}

This study was financially supported by the Collaborative Research Program (CR) under the ASEAN University Network/Southeast Asia Engineering Education Development Network (AUN/SEED-Net). 


\section{References}

[1] S. Alanya, Y.D. Yilmazel, C. Park, J.L. Willis, J. Keaney, P.M. Kohl, J.A. Hunt, and M. Duran, "Anaerobic co-digestion of sewage sludge and primary clarifier skimmings for increased biogas production," Water Science Technology, Vol. 67, pp. 174-179, 2013.

[2] J.H. Long, T.N. Aziz, F.L. de los Reyes III, and J.J. Ducoste, "Anaerobic co-digestion of fat, oil, and grease (FOG): A review of gas production and process limitations," Process Safety and Environmental Protection, Vol. 90, pp. 231-245, 2012.

[3] S. Astals, D.J. Batstone, J. Mata-Alvarez, and P.D. Jensen, "Identification of synergistic impacts during anaerobic co-digestion of organic wastes," Bioresource Technology, Vol. 169, pp. 421-427, 2014.

[4] H.S. Cho, H.S. Moon, J.Y. Lim, and J.Y. Kim, "Effect of long chain fatty acids removal as a pretreatment on the anaerobic digestion of food waste," Journal of Material Cycles and Waste Management, Vol. 15, pp. 82-89, 2013.

[5] L. Pastor, L. Ruiz, A. Pascual, and B. Ruiz, "Co-digestion of used oils and urban landfill leachates with sewage sludge and the effect on the biogas production," Applied Energy, Vol. 107, pp. 438-445, 2013.

[6] O.W. Awe, J. Lu, S. Wu, Y. Zhao, A. Nzihou, N. Lyczko, and D.P. Minh, "Effect of oil content on biogas production, process performance and stability of food waste anaerobic digestion," Waste and Biomass Valorization, Vol. 9, pp. 2295-2306, 2018.

[7] F.J. Callaghan, D.A.J. Wase, K. Thayanithy, and C.F. Forster, "Continuous codigestion of cattle slurry with fruit and vegetable wastes and chicken manure," Biomass and Bioenergy, Vol. 27, No. 1, pp. 71-77, 2002.

[8] A. Mshandete, A. Kivaisi, M. Rubindamayugi, and B. Mattiasson, "Anaerobic batch codigestion of sisal pulp and fish wastes," Bioresource Technology, Vol. 95, No. 1, pp. 19-24, 2004.

[9] A.J. Cavaleiro, D.Z. Sousa, and M.M. Alves, "Methane production from oleate: Assessing the bioaugmentation potential of Syntrophomonas zehnderi," Water Research, Vol. 44, pp. 4940-4947, 2010.

[10] M. Goberna, M.D. Goberna, M. Camacho, J.A. Lopez-Abadia, and C. García., "Codigestion, bio stimulation and bio augmentation to enhance methanation of brewer's spent grain," Waste Management and Research, Vol. 31, pp. 805-810, 2013.

[11] L.F.C Kampers, R.G.A. van Heck, S. Donati, E. Saccenti, R.J.M. Volkers, P.J. Schaap, M. Suarez-Diez, P.I. Nikel, and V.A.P. Martins dos Santos, "In silico-guided engineering of Pseudomonas putida towards growth under micro-oxic conditions," Microbial Cell Factories, Vol. 18, p. 179, 2019. doi: 10.1186/s12934-019-1227-5

[12] S.B. Sohn, T.Y. Kim, J.M. Park, and S.Y. Lee, "In silico genome-scale metabolic analysis of Pseudomonas putida KT2440 for polyhydroxyalkanoate synthesis, degradation of aromatics and anaerobic survival," Biotechnology Journal, Vol. 5, No. 7, pp. 739-750, 2010 doi: 10.1002/biot.201000124.7

[13] A. Azhdarpoor, B. Mortazavi, and G. Moussavi, "Oily wastewaters treatment using Pseudomonas sp. isolated from the compost fertilizer," Journal of Environmental Health Science and Engineering, Vol. 12, pp. 77-83, 2014. doi :/10.1186/2052-336X$12-77$

[14] C.S. Vinothini, S. Sudhakar, and R. Ravikumar, "Biodegradation of petroleum and crude oil by Pseudomonas putida and Bacillus cereus," The International Journal of Current Microbiology and Applied Science, Vol. 4, No. 1, pp. 318-329, 2015. 
[15] T.H Chrzanowski, and M. Kyle, "Ratios of carbon, nitrogen and phosphorus in Pseudomonas fluorescens as a model for bacterial element ratios and nutrient regeneration," Aquatic Microbial Ecology, Vol. 10, pp. 115-122. 1996.

[16] G.B. Kasali, E. Senior, and I.A. Watson-Craik, "Sodium bicarbonate effects on the anaerobic digestion of refuse," Journal of Chemical Technology and Biotechnology, Vol. 45, No. 4, pp. 278-289, 1989.

[17] D.J. Kim, S.G. Chung, S.H. Lee, and J.W. Choi, "Relation of microbial biomass to counting units for Pseudomonas aeruginosa," African Journal of Microbiology Research, Vol. 6, No. 21, pp. 4620-4622, 2012.

[18] APHA, Standard Methods for the Examination of Water and Wastewater, $22^{\text {nd }}$ Edition, American Public Health Association, Washington D.C., United States, 2012.

[19] B. Basak, S.M. Patil, S. Saha, M.B. Kurade, G.S. Ha, S.P. Govindwar, S.S. Lee, S.W. Chang, W.J. Chung, and B.H. Jeon, "Rapid recovery of methane yield in organic overloaded-failed anaerobic digesters through bioaugmentation with acclimatized microbial consortium," Science of the Total Environment, Vol. 764, No. 144219, 2021. doi: 10.1016/j.scitotenv.2020.144219

[20] S. Kumar, V. Mathur, S. Singh, S. Nandy, S.K. Khare, and S. Negi, "Bioremediation of waste cooking oil using a novel lipase produced by Penicillium chrysogenum SNP5 grown in solid medium containing waste grease," Bioresource Technology, Vol. 120, pp. 300-304, 2012.

[21] W. Han, P. He, Y. Lin, L. Shao, and F. Lü, "A methanogenic consortium was active and exhibited long-term survival in an extremely acidified thermophilic bioreactor," Frontiersin Microbiology, Vol. 10, No. 2757, 2019. doi: 10.3389/fmicb.2019.02757

[22] C. Polprasert, Organic Waste Recycling: Technology and Management, $2^{\text {nd }}$ Edition, John Wiley \& Sons Ltd., 1996.

[23] Y. Sun, D. Wang, J. Yan, W. Qiao, W. Wang, and T. Zhu, "Effects of lipid concentration on anaerobic co-digestion of municipal biomass wastes," Waste Management, Vol. 34, pp. 1025-1034, 2014. doi: 10.1016/j.wasman.2013.07.018

[24] J.C Kabouris, U. Tezel, S.G. Pavlostathis, M. Englemann, J.A. Dulaney, A.C. Todd, and R.A. Gillette, "Mesophilic and thermophilic anaerobic digestion of municipal sludge and fat, oil, and grease," Water Environment Research, Vol. 81, No.5, pp. 476485, 2009.

[25] A. Davidsson, C. Lovstedt, J.C. Jansen, C. Gruvberger, and H. Aspegren, "Co-digestion of grease trap sludge and sewage sludge," Waste Management, Vol. 28, No. 6, pp. 986992, 2008.

[26] S. Luostarinen, S. Luste, and M. Sillanpaa, "Increased biogas production at wastewater treatment plants through co-digestion of sewage sludge with grease trap sludge from a meat processing plant," Bioresource Technology, Vol. 100, 1, pp. 79-85, 2009. 